\title{
Bioavailability of anthropogenic radionuclides in mussels along the French Mediterranean coast
}

\author{
H. Thébault' ${ }^{1}$ M. Arnaud ${ }^{1}$, S. Charmasson ${ }^{1}$, B. Andral ${ }^{2}, Y$. Diméglio ${ }^{1}$ \\ and E. Barker \\ ${ }^{1}$ Laboratoire d'Études Radioécologiques Continentales et de la Méditerranée, Institut de \\ Radioprotection et de Sûreté Nucléaire, IFREMER, BP. 330, 83507 La Seyne-sur-Mer, \\ France, e-mail: herve.thebault@ifremer.fr \\ ${ }^{2}$ Laboratoire Côtier de Toulon, IFREMER, BP. 330, 83507 La Seyne-sur-Mer, France \\ ${ }^{3}$ Laboratoire de Mesure de la Radioactivité dans l'Environnement, Institut de Radioprotection \\ et de Sûreté Nucléaire, Bât. 501, Bois des Rames, 91400 Orsay, France
}

\begin{abstract}
Within the framework of the Water Management Master plan, a bioindicator network (RINBIO) was deployed all along the French Mediterranean coast (1,800 km), using man-made cages containing mussels (Mytilus galloprovincialis) to assess contamination by heavy metals, persistent organic products and radionuclides. The caging technique compensated for the scarcity of natural shellfish stocks in significant parts of the coast and enable comparison between sites regardless of their physicochemical and trophic characteristics. Among the 103 stations of the entire program, 40 were selected for the measurement of anthropogenic radionuclides by high-efficiency gamma-spectrometry. Biometrics parameters of the each mussel samples, including 'condition index' as an indicator of soft part growth, is correlated with radionuclides activities, to help correct raw data from differences in bioaccumulation between the various sites in relation to their trophic levels. A comprehensive picture of the distribution of radionuclides at such a large spatial scale is provided and the contribution of the Rhone River input, so far the main source for the coastal zone, is investigated.
\end{abstract}

\section{INTRODUCTION}

For European countries and candidate states, the recent EU Water Framework Directive [1] provides a new context as it projects in its first article "for hazardous substances, the cessation of discharges, emissions and losses within 20 years, with the ultimate aim of achieving concentrations in the marine environment approaching background values for naturally occurring substances and close to zero for man-made synthetic substances. This ambitious objective implies that monitoring programmes should be established in the coming years to document a coherent and comprehensive overview of the different water masses and inform on progresses towards the achievement of high water quality status.

This directive is declined regionally in France in a Water Management Plan, which proposes the implementation of a uniform, permanent and monitoring network to detect trace contaminants distribution in coastal waters at a regional scale.

Most monitoring programms now include the use of biological indicators. This is based on the assumption that levels of trace contaminants accumulated in biological tissues represent the time and space integrated value of these contaminants in the surrounding waters. High concentrations of many contaminants in bio-indicators render the measurement of contaminant concentrations technically simpler. Just as importantly, it is self-evident that concentrations of contaminants in organisms reflect the bioavailable forms of these contaminants in a given region. Variations of contaminant levels in 
tissues may reflect the variations in water and particulate contaminant concentrations, although biological variability can also affect tissue concentrations. The bio-indicator also reflects, usually through one representative species, called 'sentinel' specie [2], how much a functional group of the ecosystem can be impacted.

Ideally, species chosen as biomonitors should fulfil many criteria: they should be sedentary, easy to identify and collect, abundant throughout the year all over the monitored coast, long-lived, resistant to environmental variations of temperature, salinity or dissolved oxygen, tolerant to high levels of contaminants but net accumulators of the contaminants in question. Mussels are attractive as biomonitors: they are sessile animals, filtering large amounts of seawater to collect suspended particles. The use of mussel as a biomonitor has become, for the last 20 years, a standard practice in many national and international programs $[3,4,5]$.

In the Mediterranean Sea, the specie Mytilus galloprovincialis is widespread, but in some locations natural populations are rare or absent. The transplantation method compensated for this scarcity and allows controlling the source, age, and stage of sexual maturity of the samples. However, implementing it on a large geographic scale introduces factors such as variations in physiochemical characteristics and food availability in the immersion zones. Although the concentrations measured in the tissue are a function of bioavailable pollutant levels, the bioaccumulation factor depends on mussel growth in relation to the primary food production, or trophic capacity, of the environment [6]. Comparison of raw data on tissue concentration between sectors of different trophic potential may be misleading. A biometric parameter representing growth must be used to correct initial data and to produce reliable comparison at a large spatial scale.

\section{MATERIEL AND METHOD}

\subsection{Study area}

Mediterranean mussels, Mytilus galloprovincialis, were transplanted from a unique cultivated population located in a low contamination area (Etang de Thau) and selected in a narrow size range $(50 \mathrm{~mm})$. Mussels were immersed at the end of March and hauled out in July, 2003, along 1,800 kilometers of French Mediterranean shoreline in plastic cages using a sub-surface light mooring Figure 1). In the open sea, the stations were immersed between 20 meters (sandy littoral) and 30 meters (rocky littoral) with the cages located at mid-depth. This is considered to correspond to the mean field of dilution of land-based contamination sources.

The complete program monitoring various trace-contaminants: heavy metals, organic pollutants (pesticides, PCBs, PAHs) and radionuclides for which 41 stations were selected (including 6 stations in coastal lagoons) among the 103 transplantation sites.

\subsection{Processing data}

During this sexual rest period, the condition index (CI), defined as the ratio of the soft tissues dry weight over shell weight, appears to be a good indicator of growth rate and it is used to compare contamination between different areas. The use of linear regression analysis for each contaminant statistically infers that tissue concentration under steady state conditions can be a function of the CI. These regression lines allow normalizing the concentrations measured to a reference CI, based on the hypothesis of equal slopes. The contaminants levels are then comparable at a large spatial scale, independently of the trophic conditions prevailing around the sampling sites. [7]. Note that for most heavy metals, the body concentration is inversely proportional to CI (dilution effect by growth) and that for organic contaminants the concentration is directly proportional to CI (enrichment with storage lipidic tissues). 


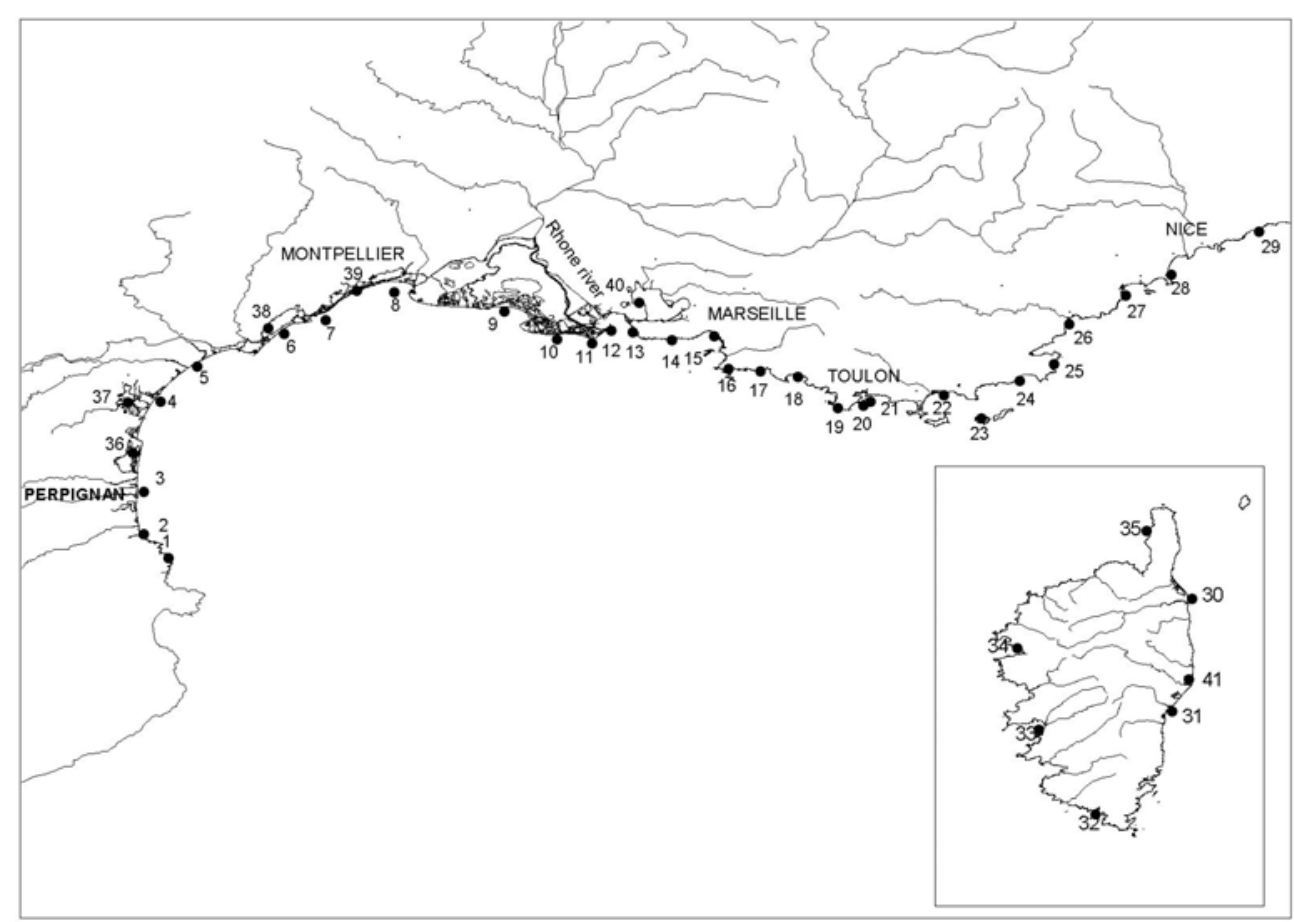

Figure 1. Location of the transplantation stations selected for radionuclides measurements.

\subsection{Sample processing and measurement}

Mussels of recovered samples were cleaned with seawater on site. In lab, mussels were opened by heat and flesh was separated from shell. Flesh is dried up at $100^{\circ} \mathrm{C}$ until constant weight and then ashed at $560^{\circ} \mathrm{C}$ for $12 \mathrm{~h}$. The remaining ashes are grounded to powder to fill $60 \mathrm{~cm}^{3}$ counting containers and shipped to the measurement laboratory. [8]

IRSN operates hyper pure, high-resolution germanium gamma direct spectrometry of trace-level radionuclides in environmental samples. Detectors are located in a room, two storeys below ground level under a $3 \mathrm{~m}$ thick borium concrete slab to reduce the impact of cosmic rays [9].

Ten N-type HP Ge detectors (Ortec GMX), each crystal $65 \mathrm{~mm}$ in diameter with a relative efficiency between $50 \%$ and $70 \%$ in respect of ${ }^{60} \mathrm{Co}$ energy are installed in one single room. The cladding in this room is lead bricks with a low background activity, $10 \mathrm{~cm}$ thick, lined with $5 \mathrm{~mm}$ thick electrolytic copper tiles neutralising lead X-ray. Each detector is insulated by a Plexiglas casing swept by gaseous nitrogen, in turn placed in a low-level activity lead enclosure $50 \mathrm{~mm}$ thick, internally lined with a $7 \mathrm{~mm}$ electrolytic copper ring.

The results are expressed in Bq. $\mathrm{kg}^{-1}$ of flesh dry weight at the sampling date.

\section{RESULTS AND DISCUSSION}

The recovery rate of samples is above $95 \%$ and mean mortality of mussel at the end of the immersion period is less than $20 \%$. The condition index (CI) ranges from 0,49 to 1,23, growth being greater in samples west of the Rhone river mouth.

Anthropogenic radionuclides of environmental concern exhibit very low levels in stations along the French Mediterranean coast: ${ }^{137} \mathrm{Cs}$ is the only artificial radionuclides regularly detected in mussels with low and stable values corresponding to the baseline levels found in the northwest part of the Mediterranean basin. ${ }^{60} \mathrm{Co}$ is sporadically measured (stations 5 , 7, and 39) at levels from 0,12 to $0,19 \mathrm{~Bq} \cdot \mathrm{kg}^{-1} \mathrm{dry}$ weight 
(Figure 2). If ${ }^{60} \mathrm{Co}$ is clearly originated from releases of nuclear facilities along the Rhone River, the input of ${ }^{137} \mathrm{Cs}$ from liquid discharges via the river is now undetectable in the distribution. When compared to previous surveys [10,11], this shows a marked decrease of this impact in the area. Indeed, the Rhone River was until now the main source of artificial radionuclides for the coastal waters with a downward influence following the prevailing westerly advective transfer along the continental shelf. The general temporal trend is also confirmed with a mean value for ${ }^{137} \mathrm{Cs}$ is $0,17 \mathrm{~Bq} \cdot \mathrm{kg}^{-1}$ dry weight in 2003 , to be compared to the mean value in 1998 and 1996, respectively 0,25 and 0,4 Bq. $\mathrm{kg}^{-1}$.

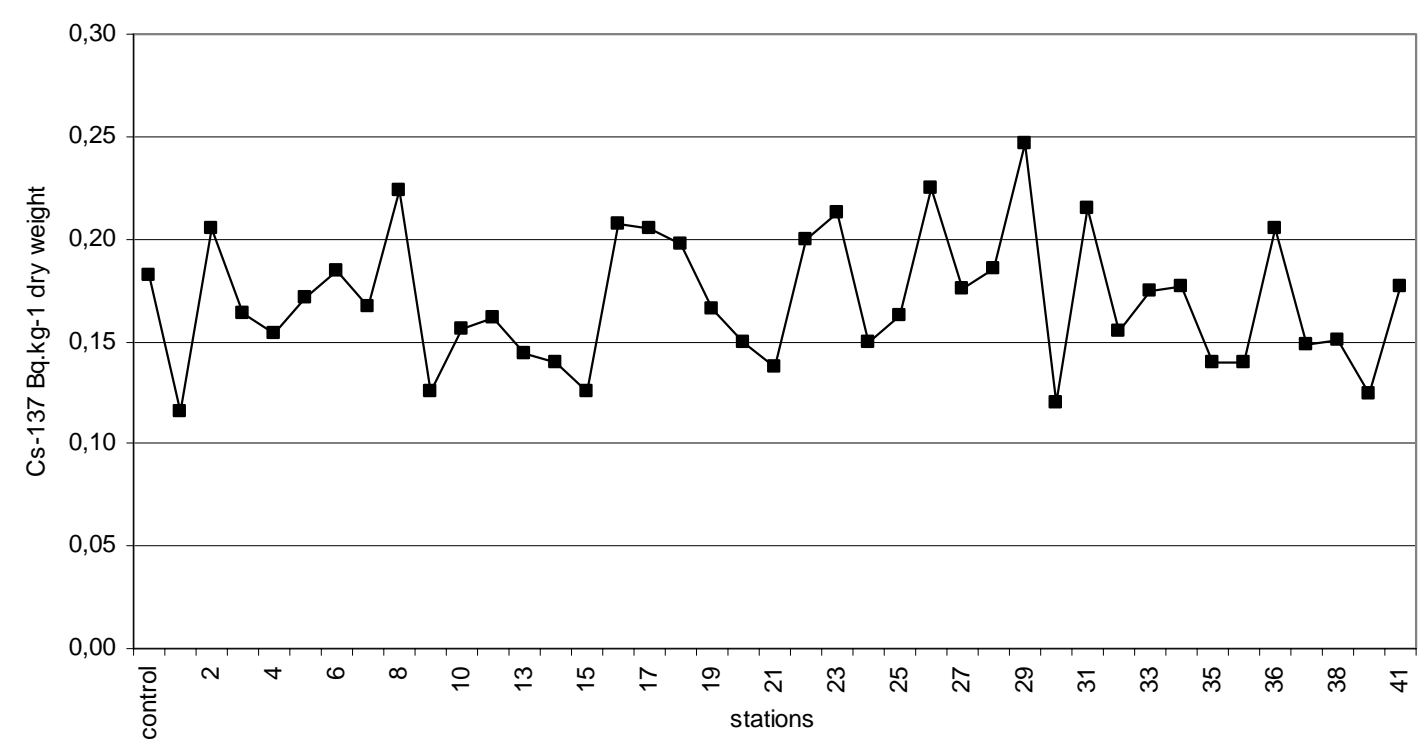

Figure 2. Distribution of ${ }^{137} \mathrm{Cs}$ in mussels transplanted along the French Mediterranean coast.

When cesium concentration is plotted against CI values, no significant correlation is found (Figure 3). Behaviour of cesium level with mussel growth appears different from most heavy metals and organic pollutants. The evident consequence is show on Figure 4, where total activity per individual is plotted against CI: the total body burden appears then correlated with growth, with increased values in the west part of the region. This suggests that the Rhone River shows an indirect influence by increasing by biological productivity of the plume dilution area.

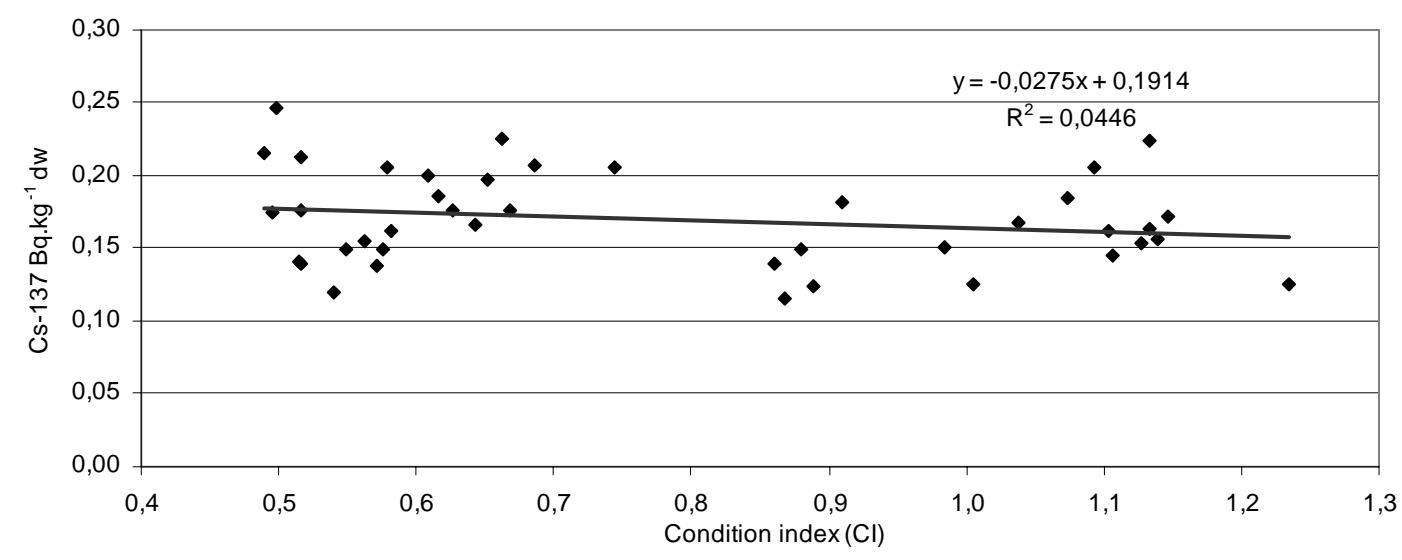

Figure 3. ${ }^{137} \mathrm{Cs}$ concentrations against Condition Index as a growth parameter for transplanted mussels. 


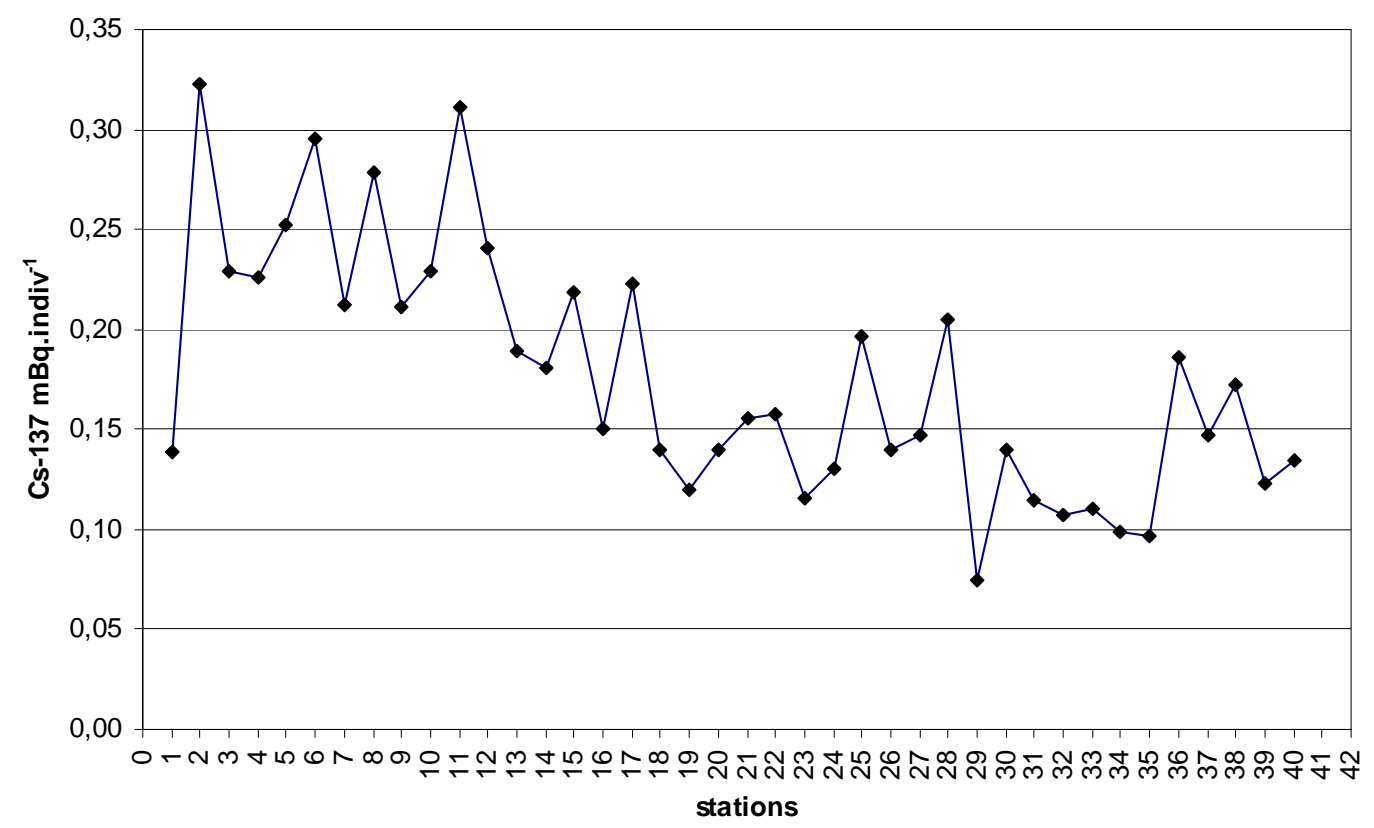

Figure 4. Distribution of ${ }^{137} \mathrm{Cs}$ total activity per individual in mussels transplanted along the French Mediterranean coast.

\section{CONCLUSION}

The transplantation of mussels in caged devices is now a mature technique, reliable for large spatial monitoring. The method requires some training of the operating team but could be easily extended to most Mediterranean coastal waters, as the specie is naturally present from the Strait of Gibraltar to the Black.

The objectives of the Water Framework Directive are almost achieved for artificial radionuclides as ${ }^{137}$ Cs concentration in bio-indicator is now close to the detection limit of the best available technique.

Liquid releases from nuclear power plants and spent fuel reprocessing plant along the Rhone river have decreased drastically in recent years and their impact in coastal waters in now undetectable in the mean field.

\section{References}

[1] Official Journal European Community (2000). Directive 2000/60/EC of the European Parliament and the Council of 23 October 2000 establishing a framework for Community action in the field of water policy. Official Journal L327, 22/12/2000, doc. 300L0060, 40 p.

[2] Goldberg E.D. (1975). The mussel watch - a first step in marine global monitoring. Marine Pollution Bulletin, 6: 111.

[3] Claisse D. (1989). Chemical contamination of the French coast, the results of a ten years Mussel Watch. Marine Pollution Bulletin 20/10: 523-528.

[4] Jernelov A. (1996). The International Mussel Watch: a global assessment of environmental levels of chemicals contaminants. Sci Total Environ 188 (suppl. 1): S37-S44.

[5] UNEP (1992). Mussel Watch worldwide literature survey. Technical Bulletins for Marine Pollution Studies 1: 142p.

[6] Nolan C. and Dahlgaard H. (1991). Accumulation of metal radiotracers by Mytilus edulis. Mar. Ecol. Prog. Serv. 70, 165 - 174. 
[7] Andral B., Stanisière J-Y., Damier E., Thébault H., Galgani F., Boissery P. (2004). Monitoring chemical contamination levels in the Mediterranean based on the use of mussel caging. Marine Pollution Bulletin, in press

[8] Charmasson S., Barker E., Calmet D., Pruchon A-S, Thébault H. (1999). Long-term variations of man-made radionuclide concentrations in a bio-indicator Mytilus galloprovincialis from the French Mediterranean Coast. Sci. Total Environ. 237/238 93-103.

[9] Bouisset P. and Calmet D. (1997). Hyper Pure Gamma-Ray Spectrometry Applied to Low-Level Environmental Sample Measurements. Proceedings of the Workshop on the Status of Measurement Techniques for the Identification of Nuclear Signatures, Geel, Belgium, 1997, ESARDA Report EUR 17312, 1997, p. 73.

[10] Thébault H., Charmasson S., Calmet D., Arnaud M., Henocque Y. (1998). The Coastal Mediterranean Monitoring Network Project: radionuclide survey. Radiation Protection Dosimetry 75 (1-4): 49-46.

[11] Andral B., Stanisière J-Y., Thébault H., Boissery P. (2001). Surveillance des niveaux de contamination chimique et radiologique en Méditerranée basée sur l'utilisation de stations artificielles de moules. Rapport 36 ${ }^{\text {ème }}$ Congrès de la CIESM vol. 36: 107. 